\title{
Prehajanje med reprezentacijami števil kot pokazatelj razumevanja pojma števil pri predšolskih otrocih
}

Jasmina Bunšek

\section{Uvod}

Prehajanje med reprezentacijami števil pri predšolskih otrocih sem raziskovala v magistrskem delu pod vodstvom dr. Tatjane Hodnik Čadež na Pedagoški fakulteti v Ljubljani. Želela sem raziskati, kako otroci pridobivajo razumevanje pojma števila. Želela sem vedeti kako prepoznati njihovo stopnjo razumevanja, da bi na podlagi tega vedela kdaj ter kakšne dejavnosti ponuditi otrokom pri svojem delu v vrtcu.

\section{Teoretična spoznanja}

V nadaljevanju bom podrobneje obravnavala in teoretično opredelila štetje, katere reprezentacije števil poznamo in razvoj pojma števila pri predšolskih otrocih.

\section{Štetje}

»V štetju je prvi smisel števil« (Ferbar, 1990: 9). Štetje je na videz enostaven proces, vendar je pravzaprav zelo kompleksno, saj je treba poznati dovolj poimenovanj (števil), da lahko preštejemo vse predmete, ki jih želimo prešteti (Liebeck, 1995). 


\section{Reprezentacije števil}

Reprezentacija je nekaj, kar stoji nekje namesto nečesa drugega (Hodnik Čadež, 2003, 2015). Prepoznavanje več različnih reprezentacij števil in sposobnost njihovega interpretiranja sta sestavna dela razumevanja števil (Powell in Nurnberger-Haag, 2015).

Razlikujemo med notranjimi in zunanjimi reprezentacijami (Hodnik Čadež, 2003, 2015). Informacije zunanjih reprezentacij niso direktno prenosljive v notranje reprezentacije. Pridobivanje znanja s pomočjo reprezentacij temelji na aktivni udeležbi otrok v procesu interpretacij reprezentacij in je med drugim odvisno tudi od otrokovega predznanja (Hodnik Čadež, 2003). Notranjih reprezentacij ne moremo neposredno opazovati (Manfreda Kolar, 2006). To je najmanj dostopno področje za pedagoške delavce in zato najbolj zanimivo (Hodnik Čadež, 2015). Naše razumevanje otrokovih notranjih reprezentacij je mogoče le $\mathrm{z}$ opazovanjem otrok pri uporabi zunanjih reprezentacij (Manfreda Kolar, 2006).

Zunanje reprezentacije števil so po V. Manfreda Kolar (2006) lahko konkretne in simbolne, po T. Hodnik Čadež (2015) pa poleg omenjenih še grafične. Po Haylocku in Cockburnu (1989, v Hodnik Čadež, 20o3) poleg vseh omenjenih še jezikovna reprezentacija.

Fizični občutek ob uporabi je pomemben vir znanja (Pimm, 1995), vendar konkretni material sam po sebi ne zagotavlja izkušnje, tudi ne vsebuje matematike in ni njen izvor. Samo ljudje s svojimi mislimi lahko osmislimo konkreten material. (Hodnik Čadež, 2003).

Grafične reprezentacije so pri učenju matematike v vrtcih najbolj zastopane v drugem starostnem obdobju. Predstavljajo nekakšen most med konkretnimi reprezentacijami in reprezentacijami z matematičnimi simboli (Hodnik Čadež, 2003).

Simbolno reprezentacijo predstavljajo matematični simboli, v predšolskem obdobju so to števke od o do 9 (Hodnik Čadež, 2003). Zapis je dvakrat odmaknjen od stvarnosti in je najbolj abstraktna oblika predstavljanja. Dekodiranje znakov za števila ne vodi samodejno do pomena. Matematični odnosi niso vgrajeni v njihove simbole. Odnose ustvari in jih tem simbolom pripiše človek (Labinowicz, 2010).

Jezikovna reprezentacija je jezik, ki je zelo pomemben medij. Z njegovo pomočjo razlagamo, hkrati pa je tudi sam po sebi reprezentacijski sistem (Hodnik Čadež, 2003). Z jezikovno reprezentacijo se praviloma otroci srečajo pred simbolno reprezentacijo (Cordes in Gelman, 2005). Govor, torej jezik, je najbolj celosten in abstrakten način predstavljanja. Čeprav 
so druge oblike predstavljanja zelo podobne predmetom ali dogodkom, ki jih simbolizirajo, govor, izražen $\mathrm{v}$ simbolih, ne spominja nanje (LabinowiCZ, 2010).

V procesu vzpostavljanja povezav med reprezentacijami od otrok pričakujemo, da odkrijejo podobnost struktur obeh reprezentacij. Odkrivanje povezave je ključnega pomena za učenje matematike $\mathrm{z}$ razumevanjem (Hodnik Čadež, 2015).

\section{Razvoj pojma števila pri predšolskem otroku}

Več avtorjev poudarja, da otroka števil ne moremo naučiti s pripovedovanjem. Ponavljanje števil po vrstnem redu v matematiki bi lahko primerjali s ponavljanjem črk v abecedi $z$ branjem (Labinowicz, 2010). Ponavljanje pa je vseeno nujna dejavnost, iz katere otrok postopno izlušči njene tipične lastnosti (Manfreda Kolar, 2006).

Strokovnjaki so različnega mnenja, pri kateri starosti in do koliko znajo šteti otroci. V. Manfreda Kolar (2006) pravi, da se otrokov razvoj koncepta od zaznavnega do abstraktnega razvije do približno sedmega leta otrokove starosti. L. Marjanovič Umek (2004) meni, da se med tretjim in petim letom zgodi pomemben prehod k razumevanju velikosti števila. Powell in Nurnberger-Haag (2015) menita, da se otroci bistvenih struktur štetja učijo med drugim in šestim letom starosti.

Otroci pojem števila osvojijo postopno. Sprva se razumevanju pojma število približa $\mathrm{z}$ razvrščanjem ena na ena (Kurikulum za vrtce, 2007). Otroci najprej premorejo le konkretno razumevanje števila. Otrok lahko usvoji koncept abstrakcije števila le na osnovi zadostnega števila konkretnih izkušenj, zato bi mu morali omogočiti dodatne konkretne izkušnje, dokler le-te ne bi izzvale spontanega procesa abstraktnega mišljenja (Manfreda Kolar, 2006).

R. Gelman in Gallistela (1978, v Manfreda Kolar, 2006) pravita, da otrok najprej šteje tudi najmanjše množice, s prakso pa si pridobi sposobnost neposrednega zaznavanja množice kot celote.

Besedno štetje je eno izmed prvih otrokovih izkušenj in spoznanj o številu (Labinowicz, 2010). Pimm (1995) meni, da ko odrasli sprašujejo otroka po štetju, navadno mislijo na besedno štetje, saj jih ne zanima, ali znajo določiti, koliko objektov določene vrste je $\mathrm{v}$ zbirki predmetov, ampak ali lahko ustvarijo pravilen določen nabor govorjenih zvokov v pravem vrstnem redu. Besedno štetje začnejo otroci usvajati med drugim in tretjim letom in se razvija še nekaj let. Veliko 2,5-letnih otrok loči besede števil od 
drugih opisnih besed. Otroci takrat praviloma še ne uporabljajo standardnega vrstnega reda števil - npr. otrok reče »tri, pet«, da prešteje dva predmeta. Otrok te starosti razume, da različna imena števil predstavljajo različne količine in da je njihovo zaporedje pomembno (Geary, 1994).

Nekateri teoretiki so mnenja, da otrokovo prve besede štetja nimajo numerične vrednosti (Cordes in Gelman, 2005). Piaget (Labinowicz, 2010) meni, da lahko ta zmožnost besednega štetja odrasle zavede k sklepanju, da otrok, ki zna šteti, tudi razume pojem števila. Sodobna generacija otrok razodeva veliko zmožnost besednega štetja, vendar ta ne izraža otrokovega razumevanja, čeprav pri štetju zelo dobro posnema odrasle. Fayol in Seron (2005) po drugi strani trdita, da ima besedno štetje vrednost. Med otrokovim razvojem se zgodi, da razume več imen za števila in jih povezujejo s kardinalnostjo, ne vedo pa, katero ime povezati s katero množico.

\section{Raziskava}

\section{Raziskovalni problem}

Že najmlajši otroci izgovarjajo številke, vendar to še ne pomeni, da znajo šteti in da razumejo pojem števila. Če otrokom reprezentiramo število na različne načine, se poznavanje pojma število pokaže v novi luči.

$\mathrm{V}$ raziskovalnem delu sem proučila in predstavila, kako otrok osvaja pojem števila do 10. Raziskovala sem, če otroci, ki dobro štejejo, tudi dobro prehajajo med reprezentacijami števil. Želim predstaviti razvoj pojma števila, opozoriti na najpogostejša napačna razumevanja, ki se pojavljajo pri pojmu števil pri 3-5-letnikih, in izpostaviti, v katerih reprezentacijah so pri določeni starosti otroci sposobni razumeti koncept števila.

Namen raziskovalnega dela je s predstavljenimi dejstvi vzgojiteljem omogočiti boljše razumevanje razvoja pojma števila, da bomo lahko načrtovali dejavnosti s števili na način, ki otrokom omogoča polno razumevanje omenjenega pojma.

\section{Raziskovalna vprašanja}

Kakšne so razlike v zmožnostih štetja pri različno starih otrocih?

Katere reprezentacije števil otroci najtežje interpretirajo in katere najlažje?

Kako otroci prehajajo med konkretno, grafično, simbolno in jezikovno reprezentacijo števil? 
Kako se otrokova zmožnost prehajanja med reprezentacijami pojma števila povezuje $\mathrm{z}$ njegovim razumevanjem pojma število?

\section{Metoda in raziskovalni pristop}

Pri raziskavi sem uporabila deskriptivno in kavzalno neeksperimentalno metodo. Raziskovalni pristop je kombinacija kvantitativne in kvalitativne raziskave.

\section{Raziskovalni vzorec}

Vzorec je bil priložnostni. Raziskavo sem opravljala junija 2016, v vseh enotah vrtca Najdihojca v Ljubljani. Sodelovalo je 48 predšolskih otrok, starih od 3 do 5 let. Za lažjo interpretacijo pridobljenih rezultatov in izpeljave določenih ugotovitev raziskave sem se omejila na starosti 3-3,5 leta, 4-4,5 leta in 5-5,5 leta. Vzorec je sestavljalo 16 otrok, starih 3-3,5 leta, 16 otrok, starih $4-4,5$ leta in 16 otrok, starih 5-5,5 leta.

\section{Postopki zbiranja podatkov}

Preden sem začela z raziskavo, sem za pridobila dovoljenje za izvajanje raziskave ravnateljice vrtca in staršev. Nisem vključila otrok, ki imajo jezikovne težave ali so v postopku pridobivanja odločbe oz. imajo odločbo otroka s posebnimi potrebami, saj sem želela dobiti posnetek otrok s pričakovanim razvojem.

Načrtovala sem, da bodo vsi intervjuji opravljeni $\mathrm{v}$ istem prostoru, da bi bili objektivni pogoji enaki, vendar se je izkazalo, da to ni mogoče. Objektivnost izpraševanja sem ohranjala tako, da so otroci vedno sedeli za mizo in da sem imeli na mizi pripomočke samo za nalogo, za katero so bili izprašani.

Intervjuji so potekali individualno $\mathrm{z}$ vsakim otrokom posebej. Podatke sem zbirala s pomočjo strukturiranega intervjuja $\mathrm{z}$ dvema sklopoma nalog. V prvem sklopu so naloge, ki pri predšolskih otrocih preverjajo uspešnost štetja, v drugem sklopu so naloge, ki preverjajo sposobnost prehajanja med reprezentacijami števil. Navodila zanje sem posredovala ustno, za vsako dejavnost sproti. Čas njihovega reševanja ni bil omejen.

Ko sem sestavljala vprašalnik, sem imela v mislih, da bi rada pridobila podatke, ki bodo raznoliki. Nisem želela, da bi bile naloge za petletnike prelahke, zato sem vključila števila do deset. Da vprašalnik ne bi bil predlog, sem se odločila, da za vsako nalogo prehajanja med reprezentacijama 
zastavim štiri primere števil. Za osnovo sem vzela dve števili do števila 5 , in dve števili od števila 6 do 10.

Opazovala sem njihovo aktivnost pri posameznih nalogah štetja ter posebnosti. Dobila sem ustne odgovore otrok ali reakcije na vprašanja, ki sem jih sproti beležila v opazovalno tabelo.

\section{Prvo raziskovalno vprašanje:}

\section{Uspešnost pri štetju glede na starost otrok}

Prvo raziskovalno vprašanje sem navezala na otrokovo uspešnost $\mathrm{v}$ povezavi s starostjo otroka. Podatke za odgovor na to vprašanje sem pridobila z vprašanjem Do koliko znaš šteti? V drugem delu sem preverjala otrokovo razumevanje načel štetja: načela urejenosti, načela povratnega enoličnega prirejanja in načela kardinalnosti.

Na vprašanje Do koliko znaš šteti? so otroci odgovarjali na različne načine. Nekateri so povedali določeno število, nekateri so skomignili z rameni, nekateri so začeli ob vprašanju šteti. Otroke, ki so bili v zadregi, sem spodbudila, da štejejo, do kolikor gre. 43,9 \% otrok, starih od 3 do 3,5 leta zna besedno šteti do 5. 50,4\%, otrok, starih od 4 do 4,5 leta, šteje do 10 ali več. Otrok, starih med 5 in 5,5 leta, ki štejejo do 10 in več, pa je 88,2 \%.

Pridobljeni rezultati potrjujejo Wynnovo (Cordes in Gelman, 2005) ugotovitev, da otroci pri približno treh letih in pol začenjajo razumeti tudi večje sklope predmetov, to je več od štirih predmetov, kar pomeni, da pri štetju več kot štirih predmetih upoštevajo vsa načela štetja.

V drugem delu sem želela dobiti podatke o štetju otrok po načelih štetja. Podatke sem pridobila $\mathrm{z}$ nalogami, ki sem jih zastavila otrokom s pomočjo lutke veverice. Vprašam jih, ali prav štejem: 3, 1, 5, 2, 8, 9, 10. Začnem šteti prste: 1,2 , preskočila tretji prst, 3, 4. Otroka vprašam, če je prav, potem drugič spet štejem prste: 1, 2, 3, 3, 4. Vprašam otroka, ali je tako prav in poskusim šteti prste še tretjič: $1,2,3$ in 4 na istem prstu, 5, 6 .

Na vprašanja za preverjanje razumevanja načela urejenosti je pravilno odgovorilo $25 \%$ otrok, starih od 3 do 3,5 leta, $62,5 \%$ otrok, starih od 4 do 4,5 leta, in vsi otroci, stari od 5 do 5,5 leta.

Fusson, 1988, Siegler in Robinson, 1982 (v Geary, 1994), pravijo, da večina 3- do 4-letnikov pozna imena števil od ena do deset v pravem vrstnem redu. Iz tega bi lahko sklepali, da je populacija našega vzorca manj uspešna pri načelu urejenosti. Po drugi strani V. Manfreda Kolar meni, da ima otrok lahko težave pri urejanju dolge liste imen števil. Manjšo uspešnost 3- 
do 3,5-letnikov in 4- do 4,5-letnikov lahko razložim $\mathrm{z}$ raziskavo Briars in Sieglerja (1984, v Manfreda Kolar, 2006), v kateri sta ugotovila, da so bili otroci manj uspešni, ko so morali potrditi ali ovreči načine štetja raziskovalca, kot pri nalogah, ko so morali sami šteti različno velike množice predmetov. Možno je tudi, da si je nekaj otrok razlagalo, da veverica pač šteje na tak način.

Uspešnih pri prepoznavanju načela povratno enoličnega prirejanja je v povprečju $25 \%$ otrok, starih od 3 do 3,5 leta, $43,8 \%$ otrok, starih od 4 do 4,5 leta, in $87,8 \%$ otrok, starih od 5 do 5,5 leta.

Načelo kardinalnosti sem preverjala s pomočjo lutke veverice, ki je na mizo postavila košaro $\mathrm{z}$ orehi in majhno posodo. Posameznega otroka sem prosila, da vanjo nabere 1 oreh. Posodo $\mathrm{z}$ nabranim orehom sem izpraznila, nato je prošnjo ponovila še za števila 3,7 in 10. Odgovore otrok sem sproti vpisovala v opazovalne tabele.

Skupno načelo kardinalnosti razume slaba polovica (43,8 \%) otrok, starih od 3 do 3,5 leta, dobra polovica (51,6 \%) otrok, starih od 4 do 4,5 leta, in večina $(84,4 \%)$ otrok, starih od 5 do 5,5 leta. Uspešnost otrok pri načelu kardinalnosti v povprečju enakomerno raste glede na starost otrok, kljub vsemu pri številu 4 preseneti enak odstotek v uspešnosti 3-3,5- in 4-4,5-letnih otrok. Eno leto predstavlja veliko razliko v razumevanju števil, zato podatek preseneti. V. Manfreda Kolar (2006) razlaga, da otrok pridobi razumevanje proceduralnih načel štetja pri starosti treh let in pol, ni pa znano, do katerega števila velja trditev. Da ni razlike med 3-3,5- in 4-4,5-letniki do števila 4, pripisujem majhnemu vzorcu. Že med samim izvajanjem sem bila v dilemi, ali so 3-letniki bolj spretni od povprečja ali pa 4-letniki malo manj spretni od povprečja. Med teoretiki je Wynn (Cordes in Gelman, 2005) v svoji raziskavi ugotovil, da so bili otroci, mlajši od 3 in pol let skoraj vedno neuspešni v nalogah tipa Podaj x živalic lutki. Potemtakem so bili 3-letni otroci $\mathrm{v}$ mojem vzorcu $\mathrm{v}$ povprečju uspešnejši.

Razbrala sem, da so otroci z vsakim letom bolj uspešni pri načelu kardinalnosti za vedno večja števila. Zakaj je bilo pri otrocih, starih od 5 do 5,5 leta, enako število pravilnih odgovorov za števili 7 in 10, pojasni Wynn (1990, 1992b, v Cordes in Gelman, 2005), ki pravi, da ko otrok enkrat osvoji štiri predmete, to naj bi bilo pri približno 3 letih in pol, potem razume tudi večje sklope predmetov.

Vsa načela štetja $v$ povprečju razume tretjina (34,4 \%) 3- do 3,5-letnih otrok, skoraj polovica $(49,2 \%)$ otrok, starih od 4 do 4,5 leta, in večina (90,6 $\%)$ otrok, starih od 5 do 5,5 leta. 
Rezultat Spearmanovega korelacijskega koeficienta kaže, da sta starost in besedno štetje močno povezana (Spearman $r=0,70$, st. pom. = o,ooo).

\section{Drugo raziskovalno vprašanje:}

Uspešnost prehajanja med reprezentacijami

Vsako prehajanje med reprezentacijami je imelo štiri števila oz. štiri možna prehajanja. Naloge prehajanja iz konkretno v jezikovno prehajanje je nalagalo, da otrok pove, koliko orehov je v posodi. Naloga konkretno-grafičnega prehajanja je otroku nalagala, da nariše, koliko orehov vidi v posodi. Pri konkretno-simbolnem prehajanju je otrok med zapisanimi števili izbral, katero predstavlja pravo število orehov v posodi. Pri grafično-konkretnem prehajanju je otrok v posodo naložil toliko orehov, kot jih je videl na sliki. Pri grafično-jezikovnem prehajanju je otrok povedal, koliko orehov vidi na sliki. Pri grafično-simbolnem prehajanju je otrok pokazal, s katerim številom napišemo, koliko je orehov na sliki. Pri jezikovno-grafičnem prehajanju je otrok dobil navodilo, da nariše določeno število orehov. Pri simbolno-grafičnem prehajanju je otrok dobil povabilo, da nariše toliko orehov, kot je zapisano na listu. Pri simbolno-konkretnem prehajanju je otrok nabral toliko orehov, kot jih je videl zapisanih s številom na listu. Pri jezikovno-konkretnem prehajanju je otrok nabral število orehov, kot ga je slišal. Pri jezikovno-simbolnem prehajanju je pokazal, kako se napiše določeno število, ki ga je slišal. Pri simbolno-jezikovnem prehajanju je otrok povedal, katero število je zapisano na listu.

Seštela sem vsa pravilna prehajanja posameznega prehoda med reprezentacijami, nato pa prehajanja med reprezentacijami uredila po številu pravilnih odgovorov.

$\mathrm{V}$ nadaljevanju $\mathrm{v}$ grafu 1 predstavljam rezultate, ki odgovarjajo na vprašanja, katere reprezentacije števil otroci najtežje interpretirajo in katere najlažje.

Rezultati v grafu 1 kažejo na to, da je od vseh prehodov med reprezentacijami otrokom najtežje prehajati iz konkretne $\mathrm{v}$ simbolno reprezentacijo. V nalogi je pravilno prehajala petina otrok (20,83 \%) otrok. Najlažje je bilo otrokom prehajati iz grafične v konkretno reprezentacijo, v povprečju sta nalogo pravilno rešili dve tretjini (69,8 \%) otrok. Zelo zanimivo je, da je bilo otrokom lažje prehajati iz grafične v konkretno in iz grafične v jezikovno reprezentacijo in ne iz konkretne $v$ grafično ali jezikovno reprezentacijo. Da je prišlo do takšnega rezultata, si razlagam s tem, da je bilo verjetno otrokom lažje šteti orehe na sliki, ki se ne premikajo, kot pa prave premi- 


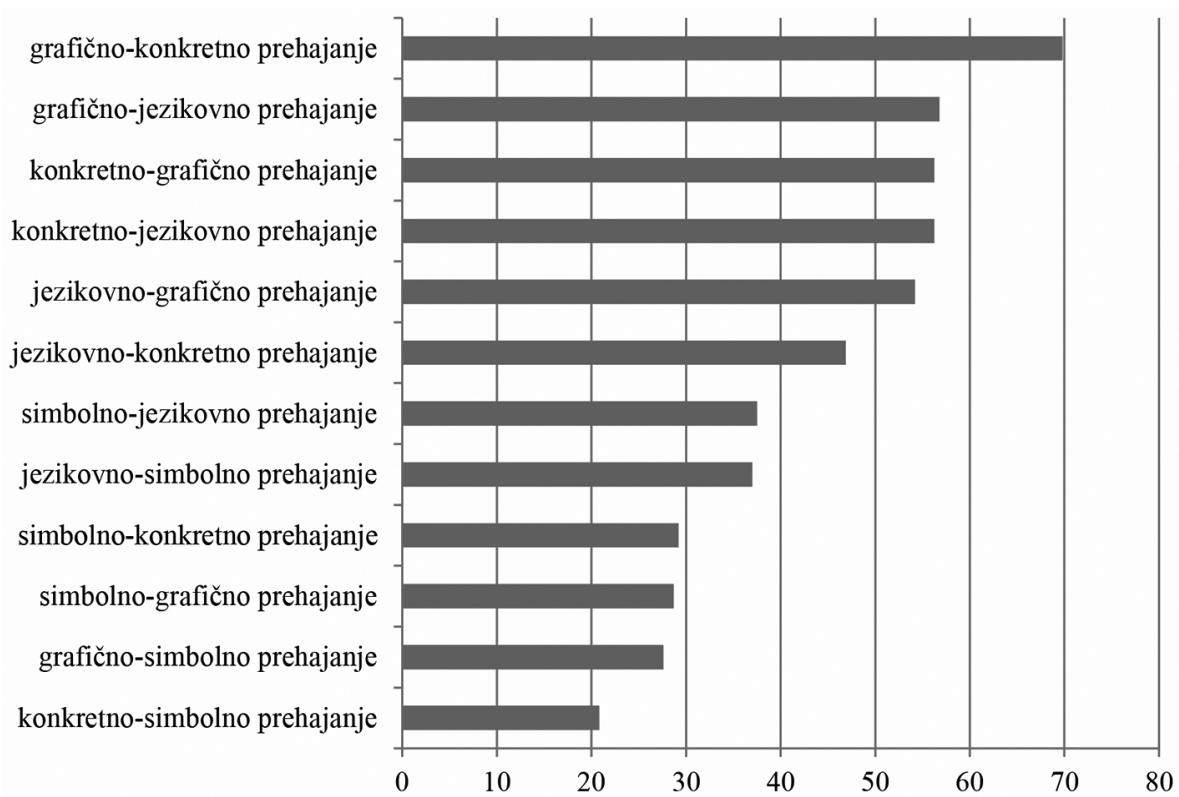

Slika ıo: Prikaz uspešnosti otrok pri različnih prehajanjih med reprezentacijami v odstotkih

kajoče se orehe, ki so poleg tega še preveliki, da bi jih otrok lahko nabral v dlan večje število itd. Omenjeni način je otroke pogosto privedel do napak pri štetju.

Opazila sem, da so v prvi polovici uspešnejših rezultatov kombinacije prehodov v konkretno, jezikovno in grafično reprezentacijo. Prisotnost simbolne reprezentacije $\mathrm{v}$ prehodih med reprezentacijami $\mathrm{v}$ drugi polovici tabele potrjuje, da otrokom ta predstavlja večjo zahtevnost.

\section{Tretje raziskovalno vprašanje:}

Načini prehajanja med reprezentacijami števil

Tu predstavljam rezultate raziskovalnega vprašanja, $v$ katerem me je zanimalo, kako otroci prehajajo med reprezentacijami števil. Prehajanje med reprezentacijami je proces, ki se zgodi v otroku samem. Kaj se zgodi, da otrok ve, kako narediti prehod iz ene v drugo reprezentacijo, lahko sklepamo iz tega, kar vidimo, da naredi. V opazovalne tabele sem skušala čim natančneje zabeležiti dejanja otrok med procesom prehajanja med posameznimi reprezentacijami.

Ugotovila sem, da pri prehajanju med reprezentacijami zasledim več različnih strategij. Nekateri otroci števila prepoznajo, pomeni, da jih zazna- 
jo intuitivno (Piaget, 1952 v Manfreda Kolar, 2006) oziroma zaznavno (Gast,1957; Pufall, Shaw in Syrdal - Larsky, 1973 v Manfreda Kolar, 2006). To pomeni, da brez štetja, le s pogledom, povejo število ali podajo ustrezno število predmetov. Praviloma prepoznavajo števila, manjša od 3.

Prepoznavanje je edina strategija, ki je otrokom služila pri prehajanjih iz simbolne v katerokoli drugo reprezentacijo in obratno. Pri prehajanjih med konkretno in grafično reprezentacijo in obratno so otroci uporabljali tudi prirejanje. Prirejanje je predhodnik štetja in je enostavnejši proces od štetja. Druge reprezentacije prirejanja ne omogočajo. Ko je bilo predstavljeno število za otroke preveliko, da bi ga prepoznali, so začeli šteti.

Opazila sem, da si otroci pri štetju pomagajo z dotikanjem predmetov ali slik med štetjem. Mlajši kot so, bolj pogosto so to počeli. Starejši kot so otroci, manj je fizičnega stika med štetjem. Sprva premikajo ali se dotikajo predmetov, kasneje s prstom od daleč štejejo, nato s kimajočo glavo in končno le še s pogledom.

Podobno je z glasnim štetjem. Starejši kot so otroci, manj je glasnega štetja. Lahko štejejo šepetaje, lahko štejejo s premikajočimi se ustnicami, lahko pa neslišno. Opazila sem, da so bolj napredne strategije lahko pripomogle tudi k več napakam. Otroci so delali več napak tudi zaradi uporabe manj zanesljivih strategij, npr. da so šteli in orehe spravljali v dlan, pri večjih številih jim zmanjka prostora v dlani in se zato izgubili, koliko so jih že prešteli, medtem ko so jih lovili, ko so jim padali iz dlani. Tudi med dotikanjem orehov so se izgubili, ko so za hip pogledali drugam.

Med dobre strategije pravilnega prehajanja med reprezentacijami spada preverjanje. Otroci, ki so preverjali, če so prav šteli, so praviloma starejši.

Nekateri otroci te starosti so v prehajanjih že bili sposobni med prehajanjem mimogrede razložiti, iz katerih dveh števil je sestavljeno določeno število. Spontano so začeli razvijati in uporabljati nove strategije pri prehajanju med reprezentacijami: računske funkcije seštevanja in odštevanja.

Nekateri otroci so si med prehajanjem med reprezentacijami pomagali tudi s prsti. Npr. da so za vsak prešteti oreh izprožili prst na roki.

Otroci so med reprezentacijami prehajali tudi neustrezno. Vsa neustrezna prehajanja otrok sem razvrstila v različne kategorije: ugibanje; veliko; najvišje število, ki ga poznam; neupoštevanje načel štetja; proceduralna napaka oz. nenatančnost; ne morem ali nočem. 
V kategoriji ugibanje otroci največkrat ugibajo o številu ali o zapisu števila, najpogosteje, ko se v prehodu med reprezentacijami pojavi simbolna reprezentacija ali višje število od otroku doslej poznanega.

V kategorijo veliko sem razvrstila vsa nepravilna prehajanja otrok, ki jim je skupno, da otroci na različne načine izražajo, da je neko število za njih večje od tega, ki ga še razumejo in ga izrazijo količinsko nedoločno.

Nedoločni pojem veliko izražajo otroci vseh treh starostnih skupin, mlajši pogosteje, starejši pa redkeje. Ko prehajajo v konkretno reprezentacijo, jo izražajo $\mathrm{z}$ nalaganjem orehov $\mathrm{v}$ dlani, da jih ne morejo več držati ali si jih nalagajo v posodo in jih kar ne nehajo nalagati. Dejanje se sklada $\mathrm{z}$ Wynnovimi ugotovitvami (Cordes in Gelman, 2005), da otrok grabi po predmetih takrat, ko ga vprašamo za število predmetov, ki ga še ni osvojil.

Ko otroci prehajajo $\mathrm{v}$ jezikovno reprezentacijo, jo izražajo $\mathrm{z}$ besedami »veliko «, »ogromno« in »zelo ogromno «. Ko prehajajo v grafično reprezentacijo, jo narišejo $\mathrm{z}$ dolgo črto, $\mathrm{z}$ risanjem krogov, kolikor je prostora na listu, $\mathrm{z}$ risanjem čačk in spiral.

V kategorijo najvišje število, ki ga poznam sem razvrstila vsa nepravilna prehajanja otrok, ko otrok ne pozna več števila, ki opisuje količino množice, ampak uporabi najvišje število, ki ga še pozna.

Neustrezna prehajanja med reprezentacijami kategorije ne morem ali nočem najbolj jasno sporočajo, da je bila naloga za otroka pretežka. Otrokov odgovor na to je bil odziv ne morem ali nočem sodelovati, kar pomeni, da je naloga zahtevala več, kot je otrok zmogel. Kategoriji zelo podobna je ugibanje. Odgovori teh otrok so jasno nakazovali, da so poskusili ugibati. Omenjeni odgovori otrok so lahko povsem osebnostnega izvora. Bolj pogumen otrok je poskusil srečo, bolj zadržanega je naloga odvrnila od reševanja. Več razumevanja števila izražata kategoriji veliko in najvišje število, ki ga poznam. Najbližje razumevanju števil so bili otroci, ki so naredili proceduralno napako, saj so odgovori izražali, da je bil otrok pri samem reševanju zgolj nenatančen $\mathrm{v}$ celotnem procesu prehajanja med reprezentacijama.

\section{Četrto raziskovalno vprašanje: Odvisnost uspešnosti prehajanja med reprezentacijami od razumevanja pojma število}

$\mathrm{V}$ tem poglavju predstavljam rezultate raziskovalnega vprašanja, pri katerem me je zanimalo, kako se povezujeta zmožnost štetja in zmožnost prehajanja med reprezentacijami števil pri predšolskem otroku. Pri reševanju tega vprašanja sem si pomagala $\mathrm{z}$ rezultati: rezultati vseh treh načel: nače- 
la urejenosti, enoličnega prirejanja in kardinalnosti glede na starost otrok ter rezultati uspešnosti pri prehajanju med reprezentacijami števil glede na starost.

Predstavljam ugotovitve rezultatov treh načel štetja - načela urejenosti, enoličnega prirejanja in kardinalnosti glede na starost otrok: vsa načela štetja $\mathrm{v}$ povprečju razume tretjina triletnikov (31,3\%), polovica štiriletnikov $(52,9 \%)$ in večina $(90,6 \%)$ petletnikov.

Predstavljam ugotovitve rezultatov uspešnosti pri prehajanju med reprezentacijami: med vsemi reprezentacijami je uspešno prehajalo 18,9 \%, 3- do 3,5-letnih otrok, 38,o \%, 4- do 4,5-letnih otrok in 73,5 \% 5- do 5,5-letnih otrok.

V Sliki 11 predstavljam števila pravilno rešenih primerov nalog o načelih štetja in število pravilnih primerov prehajanja med reprezentacijami glede na starost.

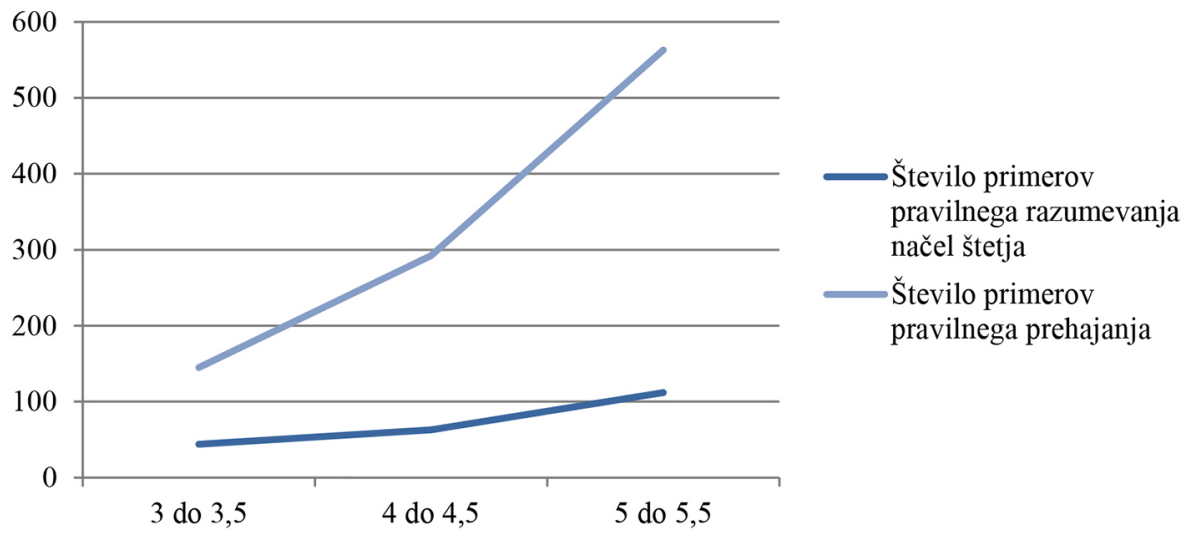

Slika Ir: Prikaz pravilnih odgovorov za razumevanje načela štetja in za prehajanja med reprezentacijami

Zanimalo me je, kakšna je povezava med rezultati otrok med štetjem in prehajanjem med reprezentacijami, zato sem uporabila Spearmanov koeficient korelacije. Povezava med štetjem in prehajanji je o,82, st. pom. = o,ooo, kar pomeni, da obstaja močna pozitivna povezava med obema dimenzijama. Če je nekdo dober pri štetju, torej razumevanju načel štetja, bo zelo dober tudi na prehajanjih in obratno. Tako visoka korelacija lahko pomeni tudi splošno raven kognitivnega razvoja otroka. 


\section{Zaključek}

$Z$ raziskavo sem ugotovila, da je prehajanje med reprezentacijami učinkovit pokazatelj otrokovega razumevanja pojma število. Ugotovila sem, da starost otrok pomembno vpliva na razumevanje števil. Vzorec raziskave je bil premajhen, da bi lahko na njegovi podlagi delala posplošene ugotovitve, podaja pa nove ideje. Zanimivo bi bilo preveriti, kako se isti posamezniki na mojem testu odrežejo pri treh, štirih in petih letih, saj bi se tako izognila morebitnim razhajanjem rezultatov med posameznimi generacijami. Prav tako bi bilo zanimivo preveriti še prehajanja v druge reprezentacije, $v$ zvočno ali v čutno. Zanimivo bi bilo raziskati prehajanje med reprezentacijami za druge matematične in ne-matematične pojme.

\section{Literatura}

Cordes, Sara. in Gelman, Rochel. The young numerical mind: When does it count?, v Handbook of Mathematical Cognition ur. Campbell, I. D. Jamie, 127-142. New York in Hove. Psychology Press, 2005.

Fayol, Michel. in Seron, Xavier. About Numerical Representations, v Handbook of Mathematical Cognition ur. Campbell, I. D. Jamie, 3-22. New York in Hove. Psychology Press, 2005.

Ferbar, Janez. Štetje. Novo mesto: Pedagoška obzorja, 1990.

Geary, C. David. Children's Mathematical Development: Research and Practical Applications. Washington: American Psychological Association, 1994.

Hodnik Čadež, Tatjana. "Poučavanje matematike u osnovnoj školi u svjetlu suvremenih istraživanja." Poučak: časopis za metodiku i nastavu matematike, letnik 15, št. 2, (2015): 4-19.

Hodnik Čadež, Tatjana. "Pomen modela reprezentacijskih preslikav za učenje računskih algoritmov." Pedagoška obzorja. Didactica Slovenica, letnik 18, št. 1. (2003): 3-21.

Kurikulum za vrtce: predšolska vzgoja $v$ vrtcih. Ljubljana: Ministrstvo za šolstvo in šport in Urad Republike Slovenije za razvoj šolstva, 2007.

Labinowicz, Ed. Izvirni Piaget. Mišljenje - Učenje - Poučevanje. Ljubljana: Državna založba Slovenije, 2010.

Liebeck, Pamela. Kako djeca uče matematiku: metodički priručnik za učitelje razredne nastave, nastavnike i profesore matematike. Zagreb: Educa, 1995.

Manfreda Kolar, Vida. Razvoj pojma število pri predšolskem otroku. Ljubljana: Univerza v Ljubljani, Pedagoška fakulteta, 2006. 
Marjanovič Umek, Ljubica. Razvojna psihologija. Ljubljana: Znanstvenoraziskovalni inštitut Filozofske fakultete, 2004.

Papalia E. Diane, Wendkos Olds, Sally in Duskin Feldman, Ruth. Otrokov svet: otrokov razvoj od spočetja do konca mladostništva. Ljubljana: Educy, 2003.

Pimm, David. Symbols and meanings in school mathematics. London and New York: Routledge, 1995.

Powell R., Sarah, Nurnberger-Haag, Julie. "Everybody Counts, but Usually Just to 10! A Systematic Analysis of Number Representations in Children's Books." Early Education and Development, vol. 26, št. 3 (2015): 377-398. 